shortly before Trump headed to Helsinki to meet with Putin, Mueller indicted twelve Russian intelligence officers for conspiracy to launder money, conspiracy to commit an offense against the United States, and, with respect to eleven of these officers, aggravated identity theft. ${ }^{38}$ "The object of the conspiracy," the indictment states, "was to hack into the computers of U.S. persons and entities involved in the 2016 U.S. presidential election, steal documents from those computers, and stage releases of the stolen documents to interfere with the 2016 U.S. presidential election."39

Congress, meanwhile, has signaled its unflagging support for NATO and continued concern regarding the threat posed by Russia. The Countering America's Adversaries Through Sanctions Act, which became law on August 2, 2017, previously expressed Congress's sense of the "vital importance" of the North Atlantic Treaty ${ }^{40}$ and imposed various sanctions on Russia. ${ }^{41}$ Consistent with this stance, the John S. McCain National Defense Authorization Act for Fiscal Year 2019, which Trump signed into law on August 13, 2018, ${ }^{42}$ described the United States as having an "ironclad commitment . . . to its obligations under the North Atlantic Treaty" and stated that the United States should pursue in coordination with NATO "an integrated approach to strengthening the defense of allies and partners in Europe as part of a broader, longer-term strategy backed by all elements of United States national power to deter and, if necessary, defeat Russian aggression." ${ }^{43}$

\title{
U.S. Supreme Court Upholds Presidential Proclamation Restricting Entry of Individuals from Covered Countries
}

doi:10.1017/ajil.2018.91

On June 26, 2018, the U.S. Supreme Court upheld President Trump's most recent iteration of restrictions on entry to the United States by nationals from certain foreign countries. ${ }^{1}$

Tweets and the Creation of "Illusory Truth," ATLANTIC (Aug. 3, 2018), at https://www.theatlantic.com/politics/ archive/2018/08/how-trumps-witch-hunt-tweets-create-an-illusory-truth/566693 (noting Trump had used "Witch Hunt" to describe the Mueller investigation at least eighty-four times in 2018).

38 See generally Indictment, United States v. Netyksho, No. 1:18-cr-00215, 2018 WL 3407381 (D.D.C filed July 13, 2018), available at https://www.documentcloud.org/documents/4598892-DNC-Hack-Indictment. html\#document [https://perma.cc/B3KC-GJ25].

39 Id., para. 20.

${ }^{40}$ Pub. L. No. 115-44, \$ 292, 131 Stat. 886, 939-40 (2017) (also stating Congress's sense that “the United States remains fully committed to the North Atlantic Treaty Organization and will honor its obligations enshrined in Article 5").

${ }^{41}$ For discussion of these sanctions and the extent to which they have been implemented by the Trump administration, see Kristina Daugirdas \& Julian Davis Mortenson, Contemporary Practice of the United States, 111 AJIL 1015, 1017-21 (2017); Jean Galbraith, Contemporary Practice of the United States, 112 AJIL 296, 296-302 (2018); Galbraith, supra note 26, at 493.

${ }^{42}$ White House Press Release, President Donald J. Trump Signs H.R. 5515 into Law (Aug. 13, 2018), at https://www.whitehouse.gov/briefings-statements/president-donald-j-trump-signs-h-r-5515-law [https:/perma. cc/HD4G-XXEH].

${ }^{43}$ Pub. L. No. 115-232, $\$ 1248($ a), _ Stat. _ (2018). For a summary of other provisions in the act, including ones relevant to NATO and Russia, see Scott R. Anderson, Sarah Tate Chambers \& Molly E. Reynolds, What's in the New NDAA, LawFARE (Aug. 14, 2018), at https://www.lawfareblog.com/whats-new-ndaa.

${ }^{1}$ Trump v. Hawaii, 138 S. Ct. 2392, 2402-06, 2423 (2018). 
Following several rewrites of this travel ban, ensuing legal challenges, and lower court injunctions, the Court, in a five-to-four decision authored by Chief Justice Roberts, reversed the latest ruling of a lower court that had granted a partial preliminary injunction against the ban. ${ }^{2}$ Although acknowledging that there was considerable evidence tying the travel ban to bias against Muslims, the Supreme Court found that the plaintiffs were nonetheless unlikely to succeed either in their statutory claim that Trump lacked the authority to impose this ban or in their constitutional claim that the ban violated the Establishment Clause of the First Amendment. ${ }^{3}$ The Court accordingly reversed the lower court's injunction and remanded the case for further proceedings. ${ }^{4}$ The ruling, based on the Trump administration's asserted national security interest, leaves in place travel restrictions imposed on nationals of seven countries-Iran, Libya, North Korea, Somalia, Syria, Venezuela, and Yemen — only two of which are not Muslim-majority countries. ${ }^{5}$

As a statutory matter, the Supreme Court found that the proclamation fell within the scope of presidential authority under the Immigration and Nationality Act (INA), which allows the president to "suspend the entry of all aliens or any class of aliens as immigrants or nonimmigrants, or impose on the entry of aliens any restrictions he may deem to be appropriate" in situations where the entry of such individuals " would be detrimental to the interests of the United States." 6 The Court found that this requirement of a presidential finding was fulfilled by actions undertaken by the Trump administration prior to the current travel ban-namely, a "worldwide, multi-agency review" of the extent to which other countries ensure the integrity of issued passports, assist in disclosing criminal history information about nationals seeking to travel to the United States, and more generally trigger national security concerns regarding terrorism. ${ }^{7}$ Additionally, though the plaintiffs argued that a separate provision of the INA prohibits discrimination based on nationality, ${ }^{8}$ the Court found that this provision was limited in applicability to those individuals deemed admissible for entry into the United States, not "the entire immigration process." Thus, this provision did not limit the president's authority to determine those eligible for admission into the country. ${ }^{10}$

The Court also rejected the plaintiffs' constitutional claim that the executive action violated the Establishment Clause, which provides that "Congress shall make no law respecting an establishment of religion." 11 In finding that the proclamation was constitutional, the Court referenced

${ }^{2} I d$. at 2406-07. For discussion of the three versions of the ban and of earlier legal proceedings relating to these versions, see Jean Galbraith, Contemporary Practice of the United States, 112 AJIL 109 (2018); Kristin Daugirdas \& Julian Davis Mortenson, Contemporary Practice of the United States, 111 AJIL 764 (2017).

${ }^{3}$ Hawaii, 138 S. Ct. at 2415, 2417-18, 2423.

${ }^{4} I d$. at 2423 .

${ }^{5}$ Id. at 2405-06, 2420-23. Plaintiffs challenged the executive action only as applicable to the five Muslimmajority countries: Iran, Libya, Somalia, Syria, and Yemen. Id. at 2406. The proclamation varied the restrictions applicable to each of the seven countries, sometimes preventing the entry of all types of travelers and sometimes only the entry of certain types of visa holders. See id. at 2405. For Venezuela, the proclamation only applied to certain government officials and their families. Id. at 2406.

${ }^{6} 8$ U.S.C. $\$ 1182(\mathrm{f}) ;$ Hawaii, 138 S. Ct. at 2415.

${ }^{7}$ Hawaii, 138 S. Ct. at 2404-05 (describing the review process, whose results produced a list of countries of concern that overlapped considerably with the countries singled out in the travel ban); 2408-09 (quoting the statutory standard and deeming the review process sufficient to satisfy this standard).

${ }^{8}$ Id. at 2413-14 (discussing Section 1152(a)(1)(A) of the INA).

${ }^{9}$ Id. at $2414-15$.

${ }^{10}$ Id. at 2415 .

${ }^{11} I d$. at 2419-22; U.S. ConsT. amend. I. 
statements by Trump on the campaign trail calling explicitly for the prevention of Muslim immigration, as well as certain statements made by Trump and his advisors after he took office that linked the travel ban with his campaign promises or more generally indicated continued antiMuslim bias. ${ }^{12}$ The Court did not find these statements dispositive, stating that:

But the issue before us is not whether to denounce the statements. It is instead the significance of those statements in reviewing a Presidential directive, neutral on its face, addressing a matter within the core of executive responsibility. In doing so, we must consider not only the statements of a particular President, but also the authority of the Presidency itself. ${ }^{13}$

In considering the constitutionality of the policy, the Court applied a rational basis standard of review. ${ }^{14}$ It stated that:

For our purposes today, we assume that we may look behind the face of the Proclamation to the extent of applying rational basis review. That standard of review considers whether the entry policy is plausibly related to the Government's stated objective to protect the country and improve vetting processes. ... As a result, we may consider plaintiffs' extrinsic evidence, but will uphold the policy so long as it can reasonably be understood to result from a justification independent of unconstitutional grounds. ${ }^{15}$

The Court found that the proclamation had "a legitimate grounding in national security concerns, quite apart from any religious hostility." 16

The Proclamation is expressly premised on legitimate purposes: preventing entry of nationals who cannot be adequately vetted and inducing other nations to improve their practices. The text says nothing about religion. Plaintiffs and the dissent nonetheless emphasize that five of the seven nations currently included in the Proclamation have Muslim-majority population. Yet that fact alone does not support an inference of religious hostility, given that the policy covers just $8 \%$ of the world's Muslim population and is limited to countries that were previously designated by Congress or prior administrations as posing national security risks. ${ }^{17}$

Three additional features of the entry policy support the Government's claim of a legitimate national security interest. First, since the President introduced entry restrictions in January 2017, three Muslim-majority countries_-Iraq, Sudan, and Chad-have been removed from the list of covered countries. The Proclamation emphasizes that its "conditional restrictions" will remain in force only so long as necessary to "address" the identified "inadequacies and risks" . . and establishes an ongoing process to engage covered nations and assess every 180 days whether the entry restrictions should be terminated. . .

\footnotetext{
${ }^{12}$ Id. at 2417-18 (discussing these statements); see also id. at 2435-37 (Sotomayor, J., dissenting) (describing these statements at more length).

${ }^{13}$ Hawaii, 138 S. Ct. at 2418.

${ }^{14}$ Id. at 2418, 2420 (citing Fiallo v. Bell, 430 U.S. 787, 792 (1977)).

${ }^{15} \mathrm{Id}$. at 2420 .

${ }^{16} I d$. at 2421 .

${ }^{17} \mathrm{Id}$.
} 
Second, for those countries that remain subject to entry restrictions, the Proclamation includes significant exceptions for various categories of foreign nationals. . . .

Third, the Proclamation creates a waiver program open to all covered foreign nationals seeking entry as immigrants or nonimmigrants. ... The Proclamation also directs DHS and the State Department to issue guidance elaborating upon the circumstances that would justify a waiver. ${ }^{18}$

Justice Kennedy and Justice Thomas each wrote concurrences. Justice Kennedy's short concurrence noted that while there "are numerous instances in which the statements and actions of Government officials are not subject to judicial scrutiny or intervention," it is nonetheless "an urgent necessity that officials adhere to [First Amendment] constitutional guarantees and mandates in all their actions, even in the sphere of foreign affairs." ${ }^{19}$ Justice Thomas's concurrence expressed doubt about the power of federal district courts to issue nationwide injunctions. ${ }^{20}$

In a dissent joined by Justice Ginsburg, Justice Sotomayor found the Trump administration's claim of a national security interest pretextual:

[The Court's decision] leaves undisturbed a policy first advertised openly and unequivocally as a "total and complete shutdown of Muslims entering the United States" because the policy now masquerades behind a facade of national-security concerns. But this repackaging does little to cleanse Presidential Proclamation No. 9645 of the appearance of discrimination that the President's words have created. ${ }^{21}$

Rejecting the majority's application of a rational basis test, Sotomayor argued that the standard should be:

whether a reasonable observer, presented with all "openly available data," the text and "historical context" of the Proclamation, and the "specific sequences of events" leading up to it, would conclude that the primary purpose of the Proclamation is to disfavor Islam and its adherents by excluding them from the country. . . The answer is unquestionably yes. ${ }^{22}$

She further concluded that even applying rational basis review, the travel ban should still fail because its existence of the policy could only be explained by animus.

The President's statements, which the majority utterly fails to address in its legal analysis, strongly support the conclusion that the Proclamation was issued to express hostility toward Muslims and exclude them from the country. Given the overwhelming record evidence of anti-Muslim animus, it simply cannot be said that the Proclamation has a legitimate basis. ${ }^{23}$

${ }^{18}$ Id. at 2422-23. The waiver program would allow individuals from covered countries to enter the United States on a case-by-case basis. Id.

${ }^{19}$ Id. at 2424 (Kennedy, J., concurring).

${ }^{20}$ Id. at 2424-25 (Thomas, J., concurring).

${ }^{21} I d$. at 2433 (Sotomayor, J., dissenting).

${ }^{22} I d$. at 2438 (Sotomayor, J., dissenting) (citation omitted).

${ }^{23}$ Id. at 2442 (Sotomayor, J., dissenting) (also concluding that the travel ban's inclusion of North Korea and Venezuela was done to "evade criticism or legal consequences for the Proclamation's otherwise clear targeting of Muslims”). Sotomayor likened the Court's decision to Korematsu v. United States, 323 U.S. 214 (1994), which had upheld the internment of U.S. citizens of Japanese dissent during World War II. Id. at 2448 (Sotomayor, J., 
In a separate dissent joined by Justice Kagan, Justice Breyer looked to the extent to which the Trump administration was making case-by-case waivers to the travel ban actually available in practice. ${ }^{24} \mathrm{He}$ reasoned that "if the Government is not applying the Proclamation's exemption and waiver system, the claim that the Proclamation is a 'Muslim ban,' rather than a 'securitybased' ban becomes much stronger." 25 Given evidence suggesting that the executive branch was failing to grant waivers in practice, he would have upheld the lower court's injunction. ${ }^{26}$

The Trump administration celebrated the Supreme Court's decision. Trump described the Court's decision as a "tremendous victory for the American people and the Constitution" and vowed to continue "fight[ing] for an immigration system that serves the national interests of the United States and its citizens." 27 By contrast, human rights groups condemned the decision, ${ }^{28}$ and Hawaii's Lieutenant Governor Doug Chin emphasized that "I hurt today for Hawaii families and others who have experienced discrimination and scapegoating due to President Trump's bullying remarks and orders."29

\section{INTERNATIONAL ORGANIZATIONS}

\section{United States Withdraws from the UN Human Rights Council, Shortly After Receiving Criticism About Its Border Policy}

doi:10.1017/ajil.2018.92

On June 19, 2018, the United States withdrew from the UN Human Rights Council. ${ }^{1}$ Announcing this decision, U.S. Ambassador to the United Nations Nikki Haley characterized the Council as "a protector of human rights abusers and a cesspool of political bias."2 U.S. Secretary of State Mike Pompeo observed that while "the United States has no opposition in

dissenting). Responding to this point, the Court stated that "Korematsu has nothing to do with this case" and described Korematsu as "gravely wrong the day it was decided." Id. at 2423.

${ }^{24}$ Id. at 2429-30 (Breyer, J., dissenting).

${ }^{25} \mathrm{Id}$. at 2430 (Breyer, J., dissenting).

${ }^{26} \mathrm{Id}$. at 2431-33 (Breyer, J., dissenting).

${ }^{27}$ Donald J. Trump, Statement on the United States Supreme Court Ruling in Trump v. Hawaii, 2018 DaILY Comp. Pres. Doc. 455 (June 26, 2018); see also U.S. Dep't of Homeland Security Press Release, DHS Statement on U.S. Supreme Court Decision on the President's Executive Order on Protecting the Nation from Foreign Terrorist Entry into the United States (June 26, 2017), at https://www.dhs.gov/news/2017/06/26/dhs-statement-us-supreme-court-decision-president-s-executive-order-protecting [https://perma.cc/7H6Z-A37S] (announcing that the decision would allow the agency to pursue "rational and necessary steps to protect [the United States] from persons looking to enter and potentially do harm").

${ }^{28}$ E.g., Amnesty International USA, Amnesty International USA Reaction to Supreme Court Ruling on Muslim Ban (June 26, 2018), at https://www.amnestyusa.org/press-releases/amnesty-international-usa-reaction-tosupreme-court-ruling-on-muslim-ban.

${ }^{29}$ The Latest: Group: Don't Base Immigration on Race, Religion, AP (June 26, 2018), at https://www.apnews. com/019fb806a05c49eab32cb1ed951af363. As Hawaii's former attorney general, Chin initially led the challenge against the executive actions. Id.

${ }^{1}$ U.S. Dep't of State Press Briefing, Remarks on the UN Human Rights Council (June 19, 2018), at https:// www.state.gov/secretary/remarks/2018/06/283341.htm [https://perma.cc/MPB4-9AQW] [hereinafter June 19 Press Briefing].

${ }^{2} I d$. 